OSEANOLOGI DAN LIMNOLOGI DI INDONESIA

Online ISSN: 2477-328X

Akreditasi RISTEKDIKTI No. 200/M/KPT/2020

http://oldi.lipi.go.id

\title{
Percampuran vertikal di Perairan Laut Maluku dan Talaud pada bulan Februari 2021
}

\author{
Adi Purwandana ${ }^{1)}$, Mochamad Riza Iskandar ${ }^{1)}$, Edikusmanto' ${ }^{1)}$, Wang Zheng ${ }^{2)}$, Muhammad Fadli3), \\ Priyadi D. Santoso ${ }^{4)}$, Corry Corvianawatie ${ }^{1)}$, Muhadjirin ${ }^{1)}$, Marlin C. Wattimena ${ }^{3)}$ \\ 1) Pusat Penelitian Oseanografi, (P2O-LIPI), Jakarta, Indonesia \\ ${ }^{2)}$ Institute of Oceanology Chinese Academy of sciences (IOCAS), Qingdao, China \\ ${ }^{3)}$ Pusat Penelitian Laut Dalam (PPLD-LIPI), Ambon, Indonesia \\ 4) Pusat Pemanfaatan dan Inovasi IPTEK (PPII-LIPI), Cibinong, Indonesia \\ *e-mail: adip001@ lipi.go.id
}

Submitted 13 Juni 2021. Reviewed 12 July 2021. Accepted 10 August 2021.

DOI: 10.14203/oldi.2021.v6i2.363

\begin{abstract}
Abstrak
Variabilitas spasial percampuran massa air di Perairan Laut Maluku bagian utara dan Perairan Talaud disajikan berdasarkan data hasil Ekspedisi Indonesia Timur (EIT) 2021 dengan menggunakan armada Kapal Riset Baruna Jaya VIII-LIPI. Disipasi energi kinetik turbulen diperoleh dengan menggunakan Metode Kunze-Williams-Briscoe (KWB) dari data CTD (Conductivity, Temperature, Depth) dan LADCP (Lowered Acoustic Doppler Current Profiler). Nilai laju disipasi energi kinetik turbulen pada lapisan inti massa air Subtropis Pasifik Utara (North Pacific Subtropical Water, NPSW) dan massa air lapisan menengah Pasifik Utara (North Pacific Intermediate Water, NPIW) memiliki orde berturut-turut $10^{-6} \mathrm{~W} / \mathrm{kg}$ dan $10^{-8} \mathrm{~W} / \mathrm{kg}$. Metode KWB yang digunakan dalam penelitian ini juga terbukti komparabel dengan Metode Thorpe.
\end{abstract}

Kata kunci: Percampuran turbulen, arus lintas Indonesia (Arlindo), Metode KWB, Metode Thorpe

\begin{abstract}
Vertical mixing in the northern Maluku Sea and Talaud Waters in February 2021. The spatial variability of water mass mixing in the northern Maluku Sea and Talaud waters are presented based on the results of Eastern Indonesia Expedition (EIT) 2021 using RV Baruna Jaya VIII-LIPI. The turbulent kinetic energy dissipation rate was obtained using the Kunze-Williams-Briscoe (KWB) Method calculated from CTD (Conductivity, Temperature, Depth) and LADCP (Lowered Acoustic Doppler Current Profiler) datasets. We found the dissipation rate in the core layer of North Pacific Subtropical Water (NPSW) and North Pacific Intermediate Water (NPIW) are in the order of $10^{-6} \mathrm{~W} / \mathrm{kg}$ and $10^{-8} \mathrm{~W} / \mathrm{kg}$, respectively. The KWB Method used in this study is also proven comparable with the Thorpe Method.
\end{abstract}

Keywords: turbulent mixing, Indonesian throughflow (ITF), KWB Method, Thorpe Method

\section{Pendahuluan}

Wilayah perairan Indonesia dikenal sebagai benua maritim, yang merupakan satusatunya wilayah perairan penghubung dua samudera di daerah lintang rendah atau ekuator, yakni Samudera Pasifik dan Samudera Hindia.
Penetrasi massa air dari Samudera Pasifik ke perairan Nusantara telah jamak diketahui sebagai bagian dari sabuk termohalin global yang berfungsi sebagai penyeimbang bahang (heat), yakni sekitar $89 \%$ dan $11 \%$ massa air yang keluar dari perairan Indonesia ke Samudera Hindia berturut-turut akan mengisi tepi barat dan tepi 
timur samudera (Zhang et al., 2019). Terobosan massa air ini juga diketahui mengontrol fluks bahang dan salinitas antara Samudera Pasifik dan Samudera Hindia, sehingga mempengaruhi siklus hidrologi di wilayah tropis (Petrick et al., 2019). Secara khusus, percampuran yang terjadi di dalam perairan internal Indonesia juga diketahui mengendalikan iklim regional (Koch-Larrouy et al., 2015; Sprintall et al., 2019).

Perairan laut Nusantara memiliki wilayahwilayah sirkulasi regional yang aktif baik dengan dinamika musiman maupun persisten sepanjang tahun, seperti arus muson yang memiliki pola pembalikan bergantung dengan arah angin muson dan arus lintas Indonesia (Arlindo) yang mengalir sepanjang tahun dari Samudera Pasifik menuju Samudera Hindia (Gordon, 2005; Song et al., 2004). Penampakan kedua tipikal arus tersebut juga sangat jelas berdasarkan kajian berbasis data observasi (Purwandana et al., 2020; Susanto et al., 2013). Kendati dikenal sebagai pintasan massa air Pasifik, hanya sekitar sepertiga massa air terobosan dari Selat Mindanao yang diteruskan masuk ke Selat Makassar (Masumoto et al., 1996). Pada jalur barat Arlindo, sebanyak 11,6 Sv $\left(1 \mathrm{~Sv}=10^{6} \mathrm{~m}^{3} / \mathrm{s}\right)$ massa air masuk ke perairan Indonesia melalui Selat Makassar (Gordon et al., 2008) dan 2,44 Sv mengalir melalui jalur timur, Selat Halmahera (Li et al., 2020). Pada beberapa lokasi ditemukan adanya pembalikan sirkulasi massa air, di antaranya di Perairan Sangihe, Perairan bagian utara Laut Maluku dan Perairan Talaud, di celah Lifamatola (Kashino et al., 1999; Purwandana et al., 2020; Tan et al., 2020; Yuan et al., 2018), atau dikenal dengan retrofleksi.

Penelitian ini difokuskan untuk mengkaji aspek percampuran vertikal massa air di Perairan Laut Maluku bagian utara dan Perairan Talaud. Sebagaimana diindikasikan dari data observasi sebelumnya (Purwandana et al., 2020; Purwandana \& Iskandar, 2020), wilayah tepi barat tropis di lintang rendah memiliki tipikal percampuran turbulen yang intensif. Namun demikian, masih terbatas pengetahuan terkait karakteristik produksi energi kinetik turbulen vertikal (properti percampuran massa air) di sekitar Laut Maluku dan Perairan Talaud. Secara spasial, wilayah ini juga memiliki variabilitas spasial arus yang cukup tinggi, yakni di bagian barat terkarakterisasi adanya aliran memasuki Laut Maluku, namun di bagian timur terjadi sebaliknya. Di Perairan Talaud, kuatnya arus balik ke Samudera Pasifik ( 2 m/s menurut kajian Purwandana et al., 2020) diduga akan memicu kuatnya sesar arus yang akan meningkatkan produksi percampuran turbulen mengingat ketidakstabilan vertikal massa air akan lebih 98 ditentukan dan lebih dikontrol oleh besarnya sesar arus dibandingkan lebih rendahnya tingkat stratifikasi massa air (Kunze et al., 1990; Pasquet et al., 2016).

\section{Metodologi}

Penelitian dilakukan dengan wahana Kapal Riset Baruna Jaya VIII LIPI pada Ekspedisi Indonesia Timur (EIT), pada bulan Februari 2021. Data oseanografi dari delapan stasiun penelitian dianalisis dalam penelitian ini (Gambar 1). Kedelapan stasiun ini dipilih karena mewakili gerbang penghubung antara perairan Laut Maluku dengan Samudera Pasifik, serta wilayah tersebut memiliki karakteristik sirkulasi massa air yang aktif. Pengukuran properti massa air, yakni suhu dan salinitas dilakukan dengan menggunakan CTD (conductivity, temperature, depth) Seabird Electronics, SBE 911 berfrekuensi $24 \mathrm{~Hz}$, sedangkan pengukuran sesar arus atau perubahan kecepatan komponen arus terhadap kedalaman pada arah zonal $(d u / d z)$ dan meridional $(d v / d z)$ dilakukan dengan menggunakan LADCP (lowered acoustic doppler current profiler) RDI Instruments berfrekuensi $1 \mathrm{~Hz}$ yang dipasang dengan mode sorot bawah (downward looking). Kedua instrumen ini dipasang dalam satu rangkaian sehingga diperoleh profil properti massa air dan sesar arus pada kedalaman dan temporal yang relatif sama.

Data CTD diproses dengan piranti SBE Data Processing, dengan perata-rataan bin $1 \mathrm{~m}$ dan ambang minimum kecepatan penurunan CTD $0,1 \mathrm{~m} / \mathrm{s}$ pada proses Loopedit. Penetapan ambang $0,1 \mathrm{~m} / \mathrm{s}$ ini ditujukan untuk mengakomodasi akuisisi data pada lapisan bawah, karena biasanya CTD diturunkan dengan kecepatan rendah pada lapisan bawah untuk menghindari kontak dengan dasar perairan. Data LADCP diekstrak dengan menggunakan piranti WINADCP untuk mendapatkan data kedalaman alat saat penurunan, komponen arus zonal $(u)$ dan arus meridional $(v)$. LADCP memiliki karakteristik zona mati atau jarak pengukuran kedalaman pertama dari alat $8,26 \mathrm{~m}$, bin kedalaman $8 \mathrm{~m}$, dan jumlah bin sebanyak 20 lapisan. LADCP diturunkan bersamaan dengan penurunan CTD dengan tipikal kecepatan penurunan $\sim 1 \mathrm{~m} / \mathrm{s}$, sehingga profil arus terukur telah cukup untuk mengisi profil arus dengan resolusi spasial $1 \mathrm{~m}$ pada saat peratarataan.

Indikasi turbulensi vertikal di kolom air dilakukan dengan menganalisis ketidakstabilan kolom air yang direpresentasikan dengan bilangan Richardson (Ri), yang didefinisikan sebagai: 


$$
R i=\frac{N^{2}}{S^{2}}
$$

dengan $N^{2}$ adalah kuadrat frekuensi daya apung $\left(\mathrm{s}^{-2}\right)$ :

$$
N^{2}=\frac{g}{\rho_{0}} \frac{d \rho}{d z}
$$

dan $S^{2}$ adalah kudrat sesar arus $\left(\mathrm{s}^{-2}\right)$ :

$$
S^{2}=\left(\frac{d u}{d z}\right)^{2}+\left(\frac{d v}{d z}\right)^{2}
$$

dengan $d u / d z$ dan $d v / d z$ berturut-turut adalah perubahan kecepatan arus terhadap kedalaman pada arah zonal dan meridional. Selanjutnya, kuantifikasi produksi turbulen atau nilai disipasi energi kinetik turbulen $\left(\mathrm{m}^{2} / \mathrm{s}^{3}\right.$ atau $\left.\mathrm{W} / \mathrm{kg}\right)$ dihitung dengan menggunakan metode parameterisasi KWB (Kunze et al., 1990; Pasquet et al., 2016):

$$
\begin{gathered}
\left\langle\epsilon_{K W B}\right\rangle=\frac{f r}{96} \Delta z^{2} N^{3}\left(\frac{1}{R i}-\frac{1}{R i_{c}}\right)\left(\frac{1}{\sqrt{R i}}\right. \\
\left.-\frac{1}{\sqrt{R i_{c}}}\right)
\end{gathered}
$$

Tanda kurung siku pada Persamaan (4) menyatakan perata-rataan spasial vertikal kolom air, yakni dipilih 50 meter karena dengan nilai perata-rataan bin ini masih representatif untuk melihat variabilitas spasial vertikal di lapisan tercampur (mixed layer), lapisan termoklin dan lapisan dalam; $f r, \Delta z$, dan $R i_{\mathrm{c}}$ berturut-turut adalah fraksi titik kedalaman dengan ketidakstabilan tinggi $(R i \leq 0.25)$, gradien kedalaman ( resolusi vertikal rata-rata pengukuran CTD-LADCP), dan ambang kritis bilangan Richardson $\left(R i_{c}=0.25\right)$.

Diketahuinya nilai disipasi energi kinetik turbulen memungkinkan untuk penghitungan nilai difusivitas vertikal $\left(\mathrm{m}^{2} / \mathrm{s}\right)$ di kolom air, yang merepresentasikan tingkat percampuran di kolom air:

$$
K_{\rho}=\Gamma \frac{\varepsilon}{N^{2}}
$$

dengan $\Gamma$ adalah efisiensi percampuran, yang secara umum ditetapkan dengan nilai $\Gamma=0.2$, yang merupakan batas atas efisiensi percampuran (Osborn, 1980).

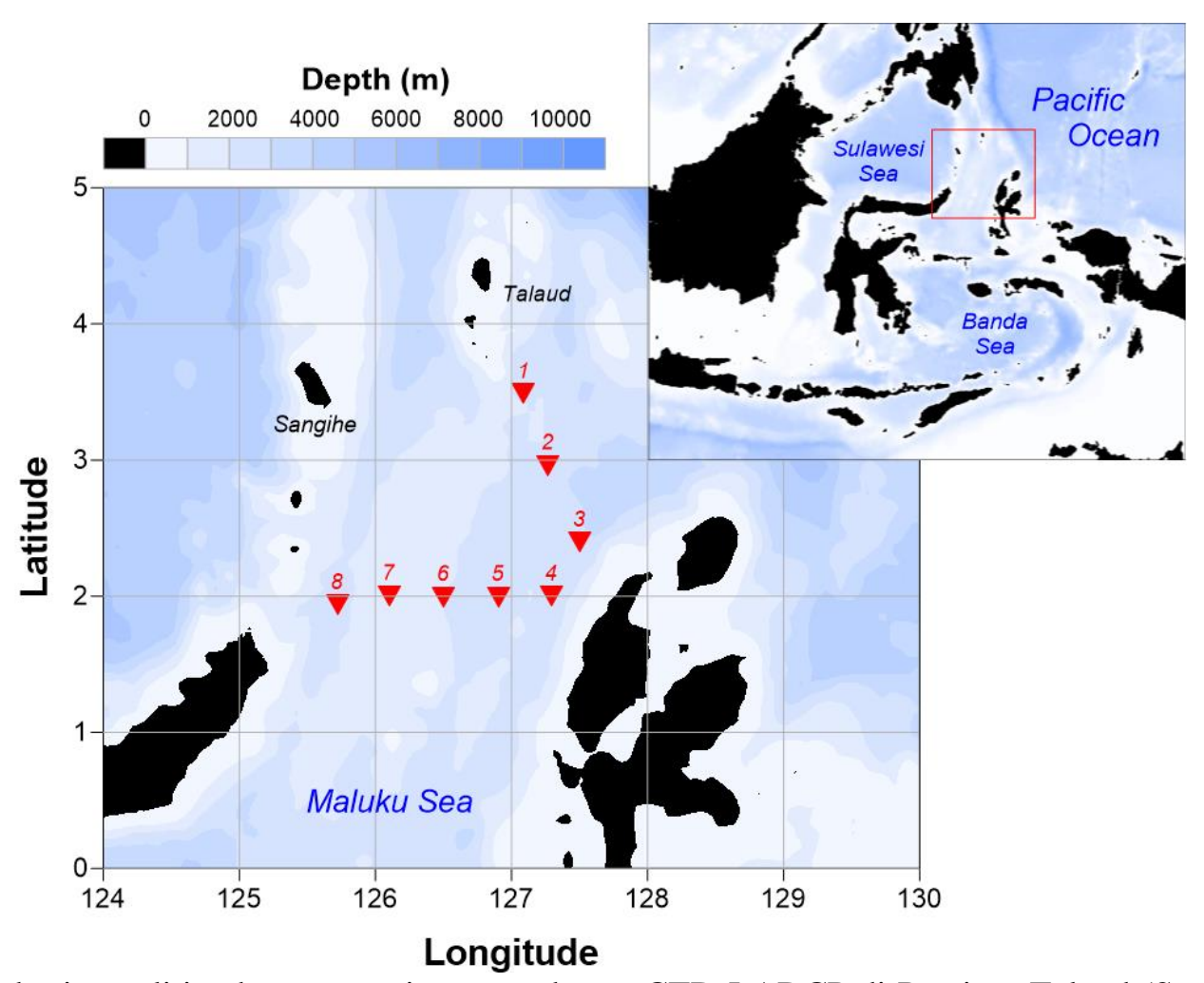

Gambar 1 Lokasi penelitian beserta stasiun pengukuran CTD-LADCP di Perairan Talaud (Stasiun 1-3) dan Laut Maluku bagian utara (Stasiun 4-8). Topografi diperoleh dari GEBCO_08 grid.

Figure 1 Location of field observations with CTD-LADCP stations in the Talaud waters (Station 1-3) and in the Maluku Sea (Station 4-8). The topography is provided by GEBCO_08 grid. 


\section{Hasil}

\section{Karakteristik massa air dan sirkulasi}

Tipikal massa air di perairan utara Laut Maluku dan perairan selatan Kepulauan Talaud diperlihatkan pada Gambar 2 dan Tabel 1. Massa air di kedua perairan memiliki struktur profil diagram T/S yang relatif sama dengan lapisan inti salinitas maksimum Massa air Subtropis Pasifik Utara (North Pacific Subtropical Water, NPSW) pada lapisan isopiknal 24-26 $\mathrm{kg} \mathrm{m}^{-3}$, dan Massa Air Lapisan Menengah Pasifik Utara (North Pacific Intermediate Water, NPIW) di Laut Maluku pada lapisan isopiknal $26-27 \mathrm{~kg} \mathrm{~m}^{-3}$, yang dikarakterisasi dengan salinitas minimum.

Sirkulasi di Perairan Talaud, sebagaimana diperlihatkan pada Gambar 2 (b, c), menunjukkan komponen zonal arah timur (positif) dan meridional utara (positif) mendominasi lapisan atas hingga kedalaman $\sim 100 \mathrm{~m}$, mengindikasikan arah relatif ke timur laut keluar menuju ke Pasifik

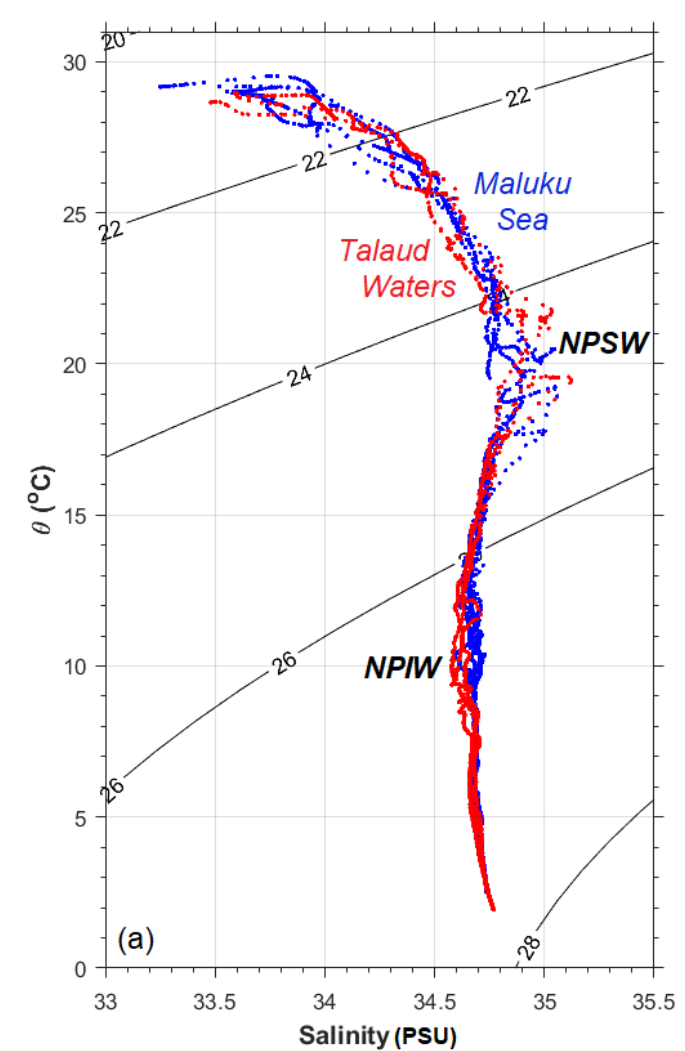

yang lebih dominan. Pada lapisan lebih dalam hingga kedalaman $\sim 2000 \mathrm{~m}$, komponen zonal arah barat (negatif) dan meridional utara (positif) mendominasi, mengindikasikan arah relatif masukan dari Pasifik. Di Laut Maluku, sebagaimana diperlihatkan pada Gambar 2 (d, e), ditemukan adanya variasi spasial. Di sisi barat $\left(125,7-126,4^{\circ} \mathrm{E}\right)$, komponen zonal arah barat (negatif) dan meridional utara (positif) mendominasi kolom perairan, mengindikasikan arus relatif ke arah barat laut namun dengan sedikit pembalikan arah menuju ke tenggara mendekati area tengah celah Laut Maluku (di atas kedalaman topografi $\sim 1400 \mathrm{~m}$ ). Di sebelah timur Laut Maluku (126,4-127,3 E), komponen zonal arah timur (positif) dan meridional utara (positif) mendominasi kolom perairan, mengindikasikan dominasi arah relatif ke timur laut, keluar menuju Pasifik.

Gambar 2 (a) Profil diagram Suhu Potensial-Salinitas (T/S) di Perairan Talaud (plot merah) dan di Laut Maluku (plot biru), (b) profil vertikal arus zonal ( $u$, negatif ke arah barat) dan (c) profil vertikal arus meridional ( $v$, negatif ke arah selatan) di Perairan Talaud; (d) profil vertikal arus zonal ( $u$ ) dan (e) profil vertikal arus meridional $(v)$ di Laut Maluku. Data arus diperoleh dari hasil pengukuran arus oleh LADCP. Topografi dasar perairan diperoleh dari GEBCO_08 grid.

Figure 2 (a) Potential temperature-Salinity (T/S) diagram in the Talaud Waters (red plots) and in the Maluku Sea (blue plots), (b) vertical profile of zonal current ( $u$, negative westward) and (c) vertical profile of meridional current ( $v$, negative southward) in the Talaud Waters; (d) vertical profile of zonal current $(u)$ and (e) vertical profile of meridional current $(v)$ in the Maluku Sea. The velocity data is gained from current measurements using LADCP. The topography is provided by GEBCO_08 grid. 
Tabel 1 Karakteristik massa air di perairan perairan utara Laut Maluku dan di perairan selatan Talaud beserta tipikal disipasi energi kinetik turbulen dan difusivitas eddy vertikal pada rentang lapisan isopiknal $\left(\mathrm{kg} / \mathrm{m}^{3}\right)$ tertentu.

Table 1 Water mass characteristics in the northern Maluku Sea waters and southern Talaud waters with typical turbulent kinetic energy dissipation rate and vertical eddy diffusivity at certain isopycnal $\left(\mathrm{kg} / \mathrm{m}^{3}\right)$ layers.

\begin{tabular}{lllllll}
\hline \multirow{2}{*}{$\begin{array}{c}\boldsymbol{\sigma}_{\boldsymbol{\theta}} \\
\left(\mathbf{k g} / \mathbf{m}^{\mathbf{3}}\right)\end{array}$} & $\boldsymbol{\theta}\left({ }^{\mathbf{0}} \mathbf{C}\right)$ & Salinity $(\mathbf{P S U})$ & \multicolumn{2}{c}{$\varepsilon_{\boldsymbol{K} W \boldsymbol{B}}(\mathbf{W} / \mathbf{k g})$} & \multicolumn{2}{c}{$\boldsymbol{K}_{\boldsymbol{\rho}}\left(\mathbf{m}^{2} / \mathbf{s}\right)$} \\
\cline { 4 - 7 } & & & mean & stdev & mean & stdev \\
\hline $\mathbf{2 1 - 2 2}$ & $27.2-29.4$ & $33.75-34.30$ & $2.6 \cdot 10^{-8}$ & $2.3 \cdot 10^{-7}$ & $2.5 \cdot 10^{-5}$ & $2.0 \cdot 10^{-4}$ \\
$\mathbf{2 2 - 2 3}$ & $24.9-27.6$ & $34.13-34.60$ & $9.3 \cdot 10^{-8}$ & $5.6 \cdot 10^{-7}$ & $9.9 \cdot 10^{-5}$ & $5.5 \cdot 10^{-4}$ \\
$\mathbf{2 3 - 2 4}$ & $22.0-25.1$ & $34.50-34.85$ & $1.5 \cdot 10^{-7}$ & $6.4 \cdot 10^{-7}$ & $1.7 \cdot 10^{-4}$ & $7.2 \cdot 10^{-4}$ \\
$\mathbf{2 4 - 2 5} *$ & $18.5-22.2$ & $34.71-35.12$ & $3.7 \cdot 10^{-6}$ & $1.6 \cdot 10^{-5}$ & $3.7 \cdot 10^{-3}$ & $1.7 \cdot 10^{-2}$ \\
$\mathbf{2 5 - 2 6}$ & $13.6-19.4$ & $34.64-35.12$ & $9.6 \cdot 10^{-7}$ & $3.4 \cdot 10^{-6}$ & $1.2 \cdot 10^{-3}$ & $3.5 \cdot 10^{-3}$ \\
$\mathbf{2 6 - 2 7} * *$ & $7.9-13.7$ & $34.57-34.73$ & $3.3 \cdot 10^{-8}$ & $1.4 \cdot 10^{-7}$ & $1.8 \cdot 10^{-4}$ & $7.3 \cdot 10^{-4}$ \\
$\mathbf{2 7 - 2 8}$ & $1.9-8.2$ & $34.64-34.77$ & $1.2 \cdot 10^{-9}$ & $8.4 \cdot 10^{-9}$ & $4.5 \cdot 10^{-5}$ & $2.1 \cdot 10^{-4}$ \\
\hline
\end{tabular}

*Lapisan termoklin lapisan inti massa air subtropis Pasifik (NPSW-North Pacific Subtropical water)

**Lapisan menengah lapisan inti massa air menengah Pasifik (NPIW-North Pacific Intermediate water).

\section{Disipasi energi kinetik turbulen}

Nilai disipasi energi kinetik turbulen di perairan Laut Maluku bagian utara dan perairan selatan Talaud terhadap kedalaman diperlihatkan pada Gambar 3 (a, b), sedangkan perata-rataan berdasarkan lapisan isopiknal ditampilkan dalam Tabel 1. Kedua perairan memiliki karakteristik disipasi energi kinetik turbulen yang relatif sama, yakni memiliki tipikal nilai disipasi energi kinetik turbulen yang tinggi dengan orde hingga $10^{-6}$ $\mathrm{W} / \mathrm{kg}$ terjadi di lapisan termoklin $<300 \mathrm{~m}\left(\sim \sigma_{\theta}=\right.$ 24-25), dan tipikal nilai menengah $10^{-8}-10^{-7} \mathrm{~W} / \mathrm{kg}$ pada kedalaman $\sim 200-500 \mathrm{~m}\left(\sim \sigma_{\theta}=26-27\right)$ dan tipikal nilai rendah kurang dari $10^{-8} \mathrm{~W} / \mathrm{kg}$ di lapisan dalam $>1000 \mathrm{~m}\left(\sim \sigma_{\theta}>26\right)$.

\section{Difusivitas eddy vertikal}

Nilai difusivitas eddy vertikal ( percampuran) di perairan Laut Maluku bagian utara dan perairan selatan Talaud terhadap kedalaman diperlihatkan pada Gambar 4 (a, b). Nilai difusivitas eddy vertikal baik di perairan Laut Maluku bagian utara maupun perairan selatan Kepulauan Talaud pada lapisan atas $(<100$ m) memiliki nilai $>5 \times 10^{-4} \mathrm{~m}^{2} / \mathrm{s}$, dan difusivitas vertikal yang rendah pada lapisan bawah $>100 \mathrm{~m}$ $\mathrm{b}$ dengan tipikal orde $10^{-4} \mathrm{~m}^{2} / \mathrm{s}$. Sebagaimana terlihat di Gambar $4(\mathrm{a}, \mathrm{b})$, difusivitas dengan nilai $>5 \times 10^{-4} \mathrm{~m}^{2} / \mathrm{s}$ cenderung terjadi di atas topografi dasar perairan yang lebih dangkal. 

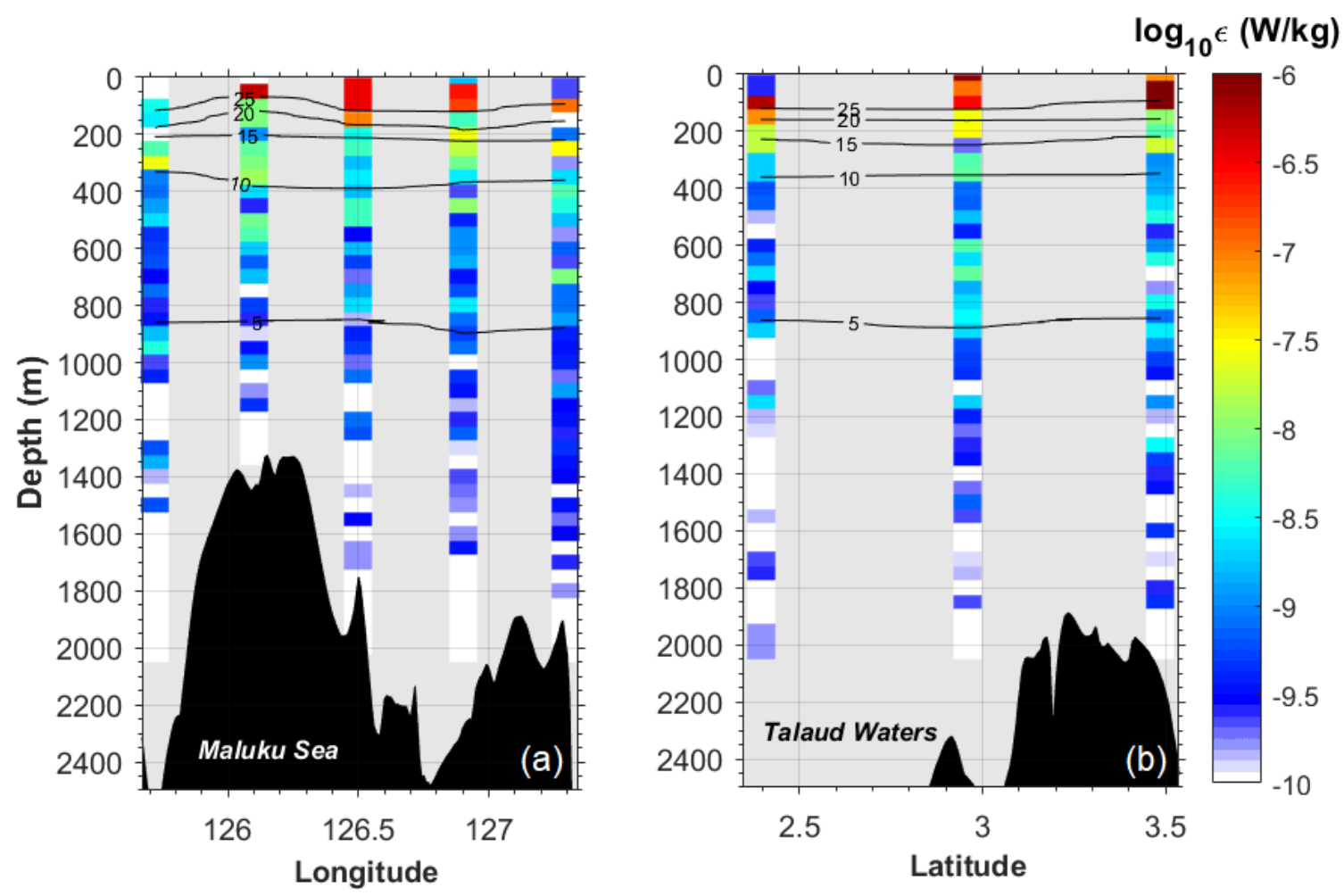

Gambar 3 Profil vertikal disipasi energi kinetik turbulen di perairan utara Laut Maluku (a) dan di perairan selatan Talaud (b) dalam skala $\log _{10}(\mathrm{~W} / \mathrm{kg})$, dengan kontur isotermal. Topografi dasar perairan diperoleh dari GEBCO_08 grid.

Figure 3 Vertical profile of the turbulent kinetic energy dissipation rate in the northern Maluku Sea waters (a) and in the southern Talaud waters (b), scaled in $\log _{10}(\mathrm{~W} / \mathrm{kg})$, with isotherm indicated. The topography is provided by GEBCO_08 grid.
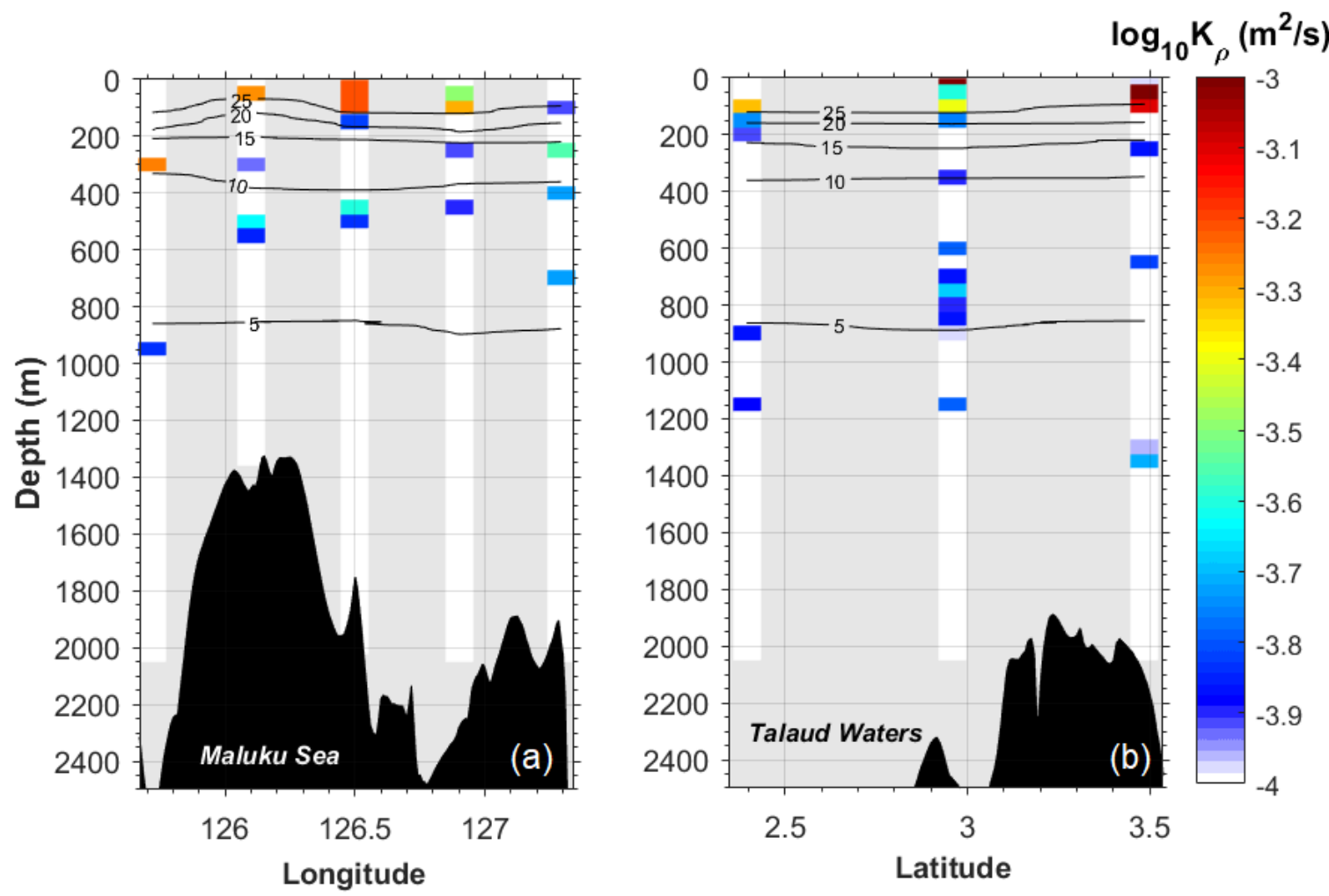

Gambar 4 Profil vertikal difusivitas eddy vertikal di perairan utara Laut Maluku (a) dan di perairan selatan Talaud (b) dalam skala $\log _{10}\left(\mathrm{~m}^{2} / \mathrm{s}\right)$. Topografi dasar perairan diperoleh dari GEBCO_08 grid.

Figure 4 Vertical profile of the vertical eddy diffusivity in the northern Maluku Sea waters (a) and in the southern Talaud waters $(\mathrm{b})$, scaled in $\log _{10}\left(\mathrm{~m}^{2} / \mathrm{s}\right)$. The topography is provided by GEBCO_08 grid. 


\section{Pembahasan}

Perairan bagian utara Laut Maluku dan perairan selatan Kepulauan Talaud memiliki karakteristik massa air yang relatif sama, yakni dengan tipikal salinitas maksimum massa air Pasifik Utara. Lapisan termoklin (NPSW) masih terdeteksi meskipun dengan intensitas yang lebih lemah dibandingkan di wilayah sumbernya, yakni di perairan sebelah timur Kepulauan Filipina (Purwandana et al., 2020). Kondisi ini disebabkan secara geografis kedua perairan ini berada pada satu sistem sirkulasi, yakni massa air Pasifik Utara yang masuk dari arah utara akibat dorongan Arus Mindanao (Mindanao Current, MC) mengumpani secara lebih dominan kedua perairan ini; serta hanya mendapatkan pengaruh minor dari massa air Pasifik Selatan yang masuk karena dorongan arus susur pesisir lapisan bawah New Guinea (New Guinea Coastal Under Current, NGCUC) (Kashino et al., 1999; Purwandana et al., 2020; Purwandana \& Iskandar, 2020). Kondisi sirkulasi di perairan selatan Talaud ini juga relatif sama dengan temuan sebelumnya (Purwandana et al., 2020), dengan adanya pembalikan arah arus menuju kembali ke Pasifik akibat retrofleksi MC.

Karakteristik laju disipasi energi kinetik turbulen yang tinggi di lapisan atas/termoklin merupakan tipikal umum. Menilik kembali konsep dasar turbulensi vertikal, pembalikan parsel kolom air yang kecil di lapisan termoklin akan membutuhkan energi turbulen yang cukup tinggi karena besarnya barrier stratifikasi pada lapisan ini. Ditambah dengan tingginya sesar arus $\left(S^{2} \sim 10^{-5} \mathrm{~s}^{-2}\right)$ ketidakstabilan sedikit saja fraksi parsel kolom air pada lapisan termoklin $<175 \mathrm{~m}$ sudah cukup untuk mengintensifkan laju disipasi energi kinetik pada lapisan ini. Adapun rendahnya nilai laju disipasi energi kinetik turbulen pada lapisan bawah berkaitan dengan stratifikasi dan sesar arus yang rendah, yang merupakan tipikal umum pada lapisan dalam $>500 \mathrm{~m}$.

Penelitian ini merupakan kajian untuk pertama kalinya di Indonesia yang berusaha mengestimasi laju disipasi energi kinetik turbulen dengan menggunakan Metode KWB. Sebelumnya, metode tak langsung yang biasa digunakan hanya menfaatkan data CTD, yakni menggunakan Metode Thorpe (Koch-Larrouy et al., 2015; Purwandana et al., 2020; Purwandana \& Iskandar, 2020). Penggunaan Metode KWB memiliki kualifikasi yang lebih baik karena tidak hanya menggunakan data stratifikasi dari CTD namun juga menggunakan data sesar arus dari LADCP. Stratifikasi merefleksikan seberapa kuat kondisi latar kolom air dalam menekan turbulensi vertikal, sedangkan sesar arus merefleksikan seberapa besar potensi energi yang diperlukan untuk menghasilkan turbulensi vertikal. Metode KWB dapat dikatakan merupakan metode transisi dari estimasi tak langsung (indirect estimates) dan metode langsung (direct estimates) menggunakan peralatan microstructure. Gambar 5c memperlihatkan komparasi profil laju disipasi energi kinetik turbulen antara Metode KWB dengan Metode Thorpe yang mengindikasikan tren profil yang relatif sama. Hanya saja, secara umum Metode Thorpe ( $\varepsilon_{\text {Th-GM }}$ dan $\left.\varepsilon_{\text {Th-Pur }}\right)$ akan cenderung memiliki profil yang terlalu tinggi (overestimate) pada parsel kolom air yang tidak stabil atau saat ada pembalikan vertikal (overturn). Namun, dengan adanya data sesar arus, maka Metode KWB akan cenderung memiliki profil laju disipasi yang relatif kontinyu karena metode ini tidak mempertimbangkan secara langsung/visual ada/tidaknya pembalikan parsel kolom air namun lebih melihat pada 'kompetisi' antara stratifikasi kolom air dari data CTD dan sesar arus dari data LADCP Gambar 5 (a, b).

Karakteristik difusivitas eddy vertikal memiliki tipikal yang sama, baik di perairan Laut Maluku maupun di perairan selatan Talaud, tinggi di lapisan atas dan rendah di lapisan bawah. Tingginya laju disipasi pada lapisan atas $<300 \mathrm{~m}$ berkaitan dengan lebih aktifnya zona sesar arus di lapisan ini ketimbang pada lapisan bawah di bawahnya. Lebih tingginya nilai difusivitas di stasiun dengan topografi yang lebih dangkal/kasar juga merupakan tipikal yang umum (Ferron et al., 2016; Purwandana et al., 2020). Distorsi salinitas maksimum pada profil diagram $\mathrm{T} / \mathrm{S}$ pada lapisan isopiknal $\sigma_{\theta}=24-25$ juga dikonfirmasi oleh tingginya nilai difusivitas vertikal sebesar $3,7 \times 10^{-}$ ${ }^{3} \mathrm{~m}^{2} / \mathrm{s}$, mengindikasikan kuatnya percampuran di lapisan inti massa air NPSW. Adapun pada lapisan menengah, lapisan inti NPIW dengan salinitas minimum pada lapisan isopiknal $\sigma_{\theta}=26$ 27 hanya mengalami percampuran sebesar $1,8 \times 10^{-4} \mathrm{~m}^{2} / \mathrm{s}$, yang ditandai dengan koyakan diagram $\mathrm{T} / \mathrm{S}$ yang lebih kecil. 

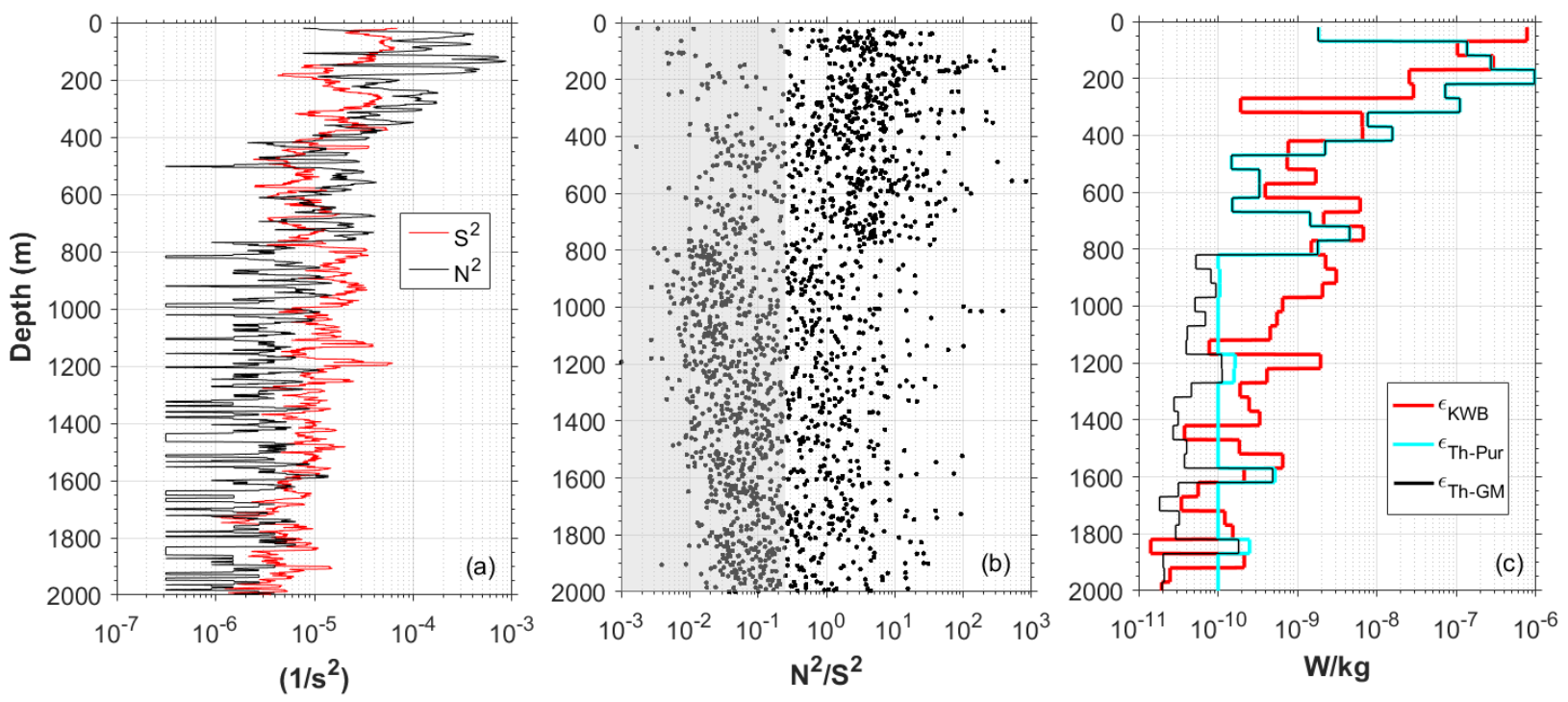

Gambar 5 Profil vertikal di Stasiun 2, Perairan Talaud : (a) stratifikasi kolom air ( $N^{2}$, plot hitam) dan sesar arus $\left(S^{2}\right.$, red plot), (b) bilangan Richardson, $R i=N^{2} / S^{2}$ dengan area arsiran adalah parsel kolom air nilai $R i<0.25$ atau parsel dengan ketidakstabilan tinggi, (c) laju disipasi energi kinetik turbulen yang dihitung menggunakan Metode Thorpe dengan latar Garret Munk ( $\varepsilon_{\mathrm{Th}-\mathrm{GM}}$, plot hitam), Metode Thorpe-Purwandana $\left(\varepsilon_{\text {Th-Pur, }}\right.$ plot cyan), dan Metode KWB ( $\varepsilon_{\mathrm{KWB}}$, plot merah).

Figure 5 Vertical profile at Station 2, Talaud waters: (a) stratification $\left(N^{2}\right.$, black plot) and shear ( $S^{2}$, red plot), (b) Richardson number, $R i=N^{2} / S^{2}$ with shaded area depicts the water column parcels with values $R i<0.25$ or highly unstable parcels, (c) turbulent kinetic energy dissipation rate, estimated using Thorpe Method ( $\varepsilon_{\mathrm{Th}}$, black plot), Thorpe-Purwandana ( $\varepsilon_{\mathrm{Th}-P u r}$, cyan plot), and kwb Method $\left(\varepsilon_{\mathrm{KWB}}\right.$, red plot).

\section{Kesimpulan}

Properti massa air di perairan Laut Maluku bagian utara dan perairan selatan Talaud memperlihatkan keberadaan tipikal massa air yang sama yakni massa air Pasifik Utara, dengan indikasi reduksi salinitas maksimum massa air Pasifik subtropis utara (NPSW) di lapisan termoklin dan melemahnya lapisan salinitas minimum massa air lapisan menengah Pasifik Utara (NPIW). Aliran balik retrofleksi massa air dari Laut Maluku dan perairan Talaud menciptakan sesar arus yang kuat pada lapisan atas, menghasilkan laju disipasi energi kinetik turbulen yang kuat, yang mengonfirmasi terdegradasinya tipikal lapisan inti massa air Pasifik Utara di wilayah ini. Penggunaan Metode KWB terbukti komparabel dengan Metode Thorpe, dengan kualifikasi spasial vertikal yang lebih baik. Sayangnya, hingga saat ini belum ada pengukuran dengan metode langsung menggunakan microstructure, baik di perairan Talaud maupun Laut Maluku yang dapat digunakan untuk mengonfirmasi estimasi metode tak langsung yang digunakan dalam penelitian ini.

\section{Ucapan Terimakasih}

Penulis pertama (Adi Purwandana) adalah kontributor utama manuskrip ini. Penulis menyampaikan terimakasih kepada Kapten Indrayana Hasan dan seluruh Kru Baruna Jaya VIII, Koordinator Kapal Riset Pusat Pemanfaatan dan Inovasi IPTEK LIPI, Bu Indriyani; Kepala Pusat Penelitian Oseanografi LIPI, Dr. Augy Syahailatua dan Koordinator Ekspedisi Indonesia Timur 2021, Dr. Nugroho Dwi Hananto.

\section{Daftar Pustaka}

Ferron, B., Kokoszka, F., Mercier, H., Lherminier, P., Huck, T., Rios, A., \& Thierry, V. (2016). Variability of the turbulent kinetic energy dissipation along the A25 Greenland-Portugal transect repeated from 2002 to 2012. Journal of Physical Oceanography, 46(7), 1989-2003. doi: 10.1175/JPO-D-15-0186.1

Gordon, A. L. (2005). Oceanography of the Indonesian Seas and their throughflow. Oceanography, 18(4), 14-27. doi: 10.5670/oceanog.2005.18

Gordon, A. L., Susanto, R. D., Ffield, A., Huber, B. A., Pranowo, W., \& Wirasantosa, S. 
(2008). Makassar Strait throughflow, 2004 to 2006. Geophysical Research Letters, 35(24). doi: 10.1029/2008GL036372

Kashino, Y., Watanabe, H., Herunadi, B., Aoyama, M., \& Hartoyo, D. (1999). Current variability at the Pacific entrance of the Indonesian Throughflow. Journal of Geophysical Research: Oceans, 104(C5), 11021-11035. doi: 10.1029/1999JC900033

Koch-Larrouy, A., Atmadipoera, A., van Beek, P., Madec, G., Aucan, J., Lyard, F., Grelet, J., \& Souhaut, M. (2015). Estimates of tidal mixing in the Indonesian archipelago from multidisciplinary INDOMIX in-situ data. Deep-Sea Research Part I: Oceanographic Research Papers, 106, 136-153. doi: 10.1016/j.dsr.2015.09.007

Kunze, E., Williams, A. J., \& Briscoe, M. G. (1990). Observations of Shear and Vertical Stability From a Neutrally Buoyant Float. Journal of Geophysical Research, 95(C10), 18,217-18,142. doi: 10.1029/jc095ic10p18127

Li, X., Yuan, D., Wang, Z., Li, Y. A. O., Corvianawatie, C., Surinati, D., Sandra, A., Bayhaqi, A., Avianto, P., Kusmanto, E., Dirhamsyah, D., \& Arifin, Z. (2020). Moored observations of transport and variability of halmahera sea currents. Journal of Physical Oceanography, 50(2), 471-488. doi: 10.1175/JPO-D-19-0109.1

Masumoto, Y., \& Yamagata, T. (1996). Seasonal variations of the Indonesian throughflow in a general ocean circulation model. Journal of Geophysical Research, 101(C5), 12,287$12,293$.

Osborn, T. R. (1980). Estimates of the Local Rate of Vertical Diffusion from Dissipation Measurements. In Journal of Physical Oceanography (Vol. 10, Issue 1, pp. 8389). doi: 10.1175/1520-0485(1980)010 <0083:EOTLRO> 2.0.CO;2

Pasquet, S., Bouruet-aubertot, P., Reverdin, G., Turnherr, A., \& St. Laurent, L. (2016). Deep-Sea Research I Finescale parameterizations of energy dissipation in a region of strong internal tides and sheared $\mathrm{fl}$ ow , the Lucky-Strike segment of the MidAtlantic Ridge. Deep-Sea Research Part I, 112, 79-93. doi: 10.1016/j.dsr.2015.12.016

Petrick, B., Martínez-García, A., Auer, G., Reuning, L., Auderset, A., Deik, H., Takayanagi, H., De Vleeschouwer, D., Iryu, Y., \& Haug, G. H. (2019). Glacial Indonesian Throughflow weakening across the Mid-Pleistocene Climatic Transition. Scientific Reports, 9(1), 16995. doi:

\subsection{8/s41598-019-53382-0}

Purwandana, A., Cuypers, Y., Bouruet-Aubertot, P., Nagai, T., Hibiya, T., \& Atmadipoera, A. S. A. S. (2020). Spatial structure of turbulent mixing inferred from historical CTD datasets in the Indonesian seas. Progress in Oceanography, 184, 102312. doi: 10.1016/j.pocean.2020.102312

Purwandana, A., \& Iskandar, M. R. (2020). Turbulent Mixing Inferred from CTD Datasets in the Western Tropical Pacific Ocean. Indonesian Journal of Marine Sciences, 25(4), 148-156.

Purwandana, A., Surinati, D., Bayhaqi, A., Azis Ismail, M. F., Corvianawatie, C., Budiman, A. S., Edikusmanto, Irianto, D., \& Muhadjirin. (2020). The spatial current structure in the Indonesian Seas in November 2014, during The Expedition of Widya Nusantara (EWIN). Oseanologi Dan Limnologi Di Indonesia, 5(3), 161-170. doi: 10.14203/oldi.2020.v5i3.330

Song, Q., Gordon, A. L., \& Visbeck, M. (2004). Spreading of the Indonesian throughflow in the Indian Ocean. Journal of Physical Oceanography, 34(4), 772-792. doi: $10.1175 / 1520-$ 0485(2004)034<0772:SOTITI >2.0.CO;2

Sprintall, J., Gordon, A. L., Wijffels, S. E., Feng, M., Hu, S., Koch-Larrouy, A., Phillips, H., Nugroho, D., Napitu, A., Pujiana, K., Susanto, R. D., Sloyan, B., Peña-Molino, B., Yuan, D., Riama, N. F., Siswanto, S., Kuswardani, A., Arifin, Z., Wahyudi, A. J., ... Setiawan, A. (2019). Detecting Change in the Indonesian Seas. In Frontiers in Marine Science (Vol. 6, p. 257). Retrieved from

https://www.frontiersin.org/article/10.3389/ fmars.2019.00257

Susanto, R. D., Wei, Z., Adi, R. T., Fan, B., Li, S., \& Fang, G. (2013). Observations of the Karimata Strait througflow from December 2007 to November 2008. Acta Oceanologica Sinica, 32(5), 1-6. doi: 10.1007/s13131-013-0307-3

Tan, S., Pratt, L. J., Yuan, D., Li, X., Wang, Z., Li, Y., Corvianawatie, C., Surinati, D., Sandra, A., \& Bayhaqi, A. (2020). Hydraulics and mixing of the deep overflow in the Lifamatola Passage of the Indonesian seas. Journal of Physical Oceanography, 1-52. doi: 10.1175/JPO-D19-0326.1

Yuan, D., Li, X., Wang, Z., Li, Y., Wang, J., Yang, Y., Hu, X., Tan, S., Zhou, H., Wardana, A. K. A. K., Surinati, D., 
Purwandana, A., Ismail, M. F. A., Avianto, P., Dirhamsyah, D., Arifin, Z., Von Storch, J.-S., Azis Ismail, M. F., Avianto, P., ... Storch, J.-S. von. (2018). Observed transport variations in the Maluku Channel of the Indonesian seas associated with western boundary current changes. Journal of Physical Oceanography, 48(8), 18031813. doi: 10.1175/JPO-D-17-0120.1

Zhang, T., Wang, W., Xie, Q., \& Chen, L. (2019). Heat contribution of the Indonesian throughflow to the Indian Ocean. Acta Oceanologica Sinica, 38(4), 72-79. doi: 10.1007/s13131-019-1414-6 